芹田 良平

東京歯科大学市川総合病院麻酔科

（２72-8513千葉県市川市菅野5-11-13）

\section{Clinical features of myocardial dysfunction in sepsis}

Key words: (1) myocardial dysfunction, (2) sepsis

\section{Ryohei Serita}

Department of Anesthesiology, Tokyo Dental College Ichikawa General Hospital

5-11-13 Sugano, Ichikawa, Chiba 272-8513, Japan

J Jpn Soc Intensive Care Med 2012;19:312-4.

\section{文 献}

1) Dombrovskiy VY, Martin AA, Sunderram J, et al. Rapid increase in hospitalization and mortality rates for severe sepsis in the United States: a trend analysis from 1993 to 2003. Crit Care Med 2007;35:1244-50.

2) Parker MM, Shelhamer JH, Bacharach SL, et al. Profound but reversible myocardial depression in patients with septic shock. Ann Intern Med 1984;100:483-90.

3) Hunter JD, Doddi M. Sepsis and the heart. Br J Anaesth 2010;104:3-11.

4) 川口亮一, 住田臣造, 小林 嚴, 他. 経過中にST上昇を 認めた毒素性ショック症候群の 1 症例。 日集中医誌 2012; 19:384-8.

5) Zanotti-Cavazzoni SL, Hollenberg SM. Cardiac dysfunction in severe sepsis and septic shock. Curr Opin
Crit Care 2009;15:392-7.

6) Hochstadt A, Meroz Y, Landesberg G. Myocardial dysfunction in severe sepsis and septic shock: more questions than answers? J Cardiothorac Vasc Anesth 2011;25:526-35.

7) Merx MW, Weber C. Sepsis and the heart. Circulation 2007;116:793-802.

8) Markou N, Gregorakos L, Myrianthefs P. Increased blood troponin levels in ICU patients. Curr Opin Crit Care 2011;17:454-63.

9) Noveanu M, Mebazaa A, Mueller C. Cardiovascular biomarkers in the ICU. Curr Opin Crit Care 2009;15: $377-83$.

10) Vieillard-Baron A, Caille V, Charron C, et al. Actual incidence of global left ventricular hypokinesia in adult septic shock. Crit Care Med 2008;36:1701-6.

11) Morelli A, De Castro S, Teboul JL, et al. Effects of levosimendan on systemic and regional hemodynamics in septic myocardial depression. Intensive Care Med 2005; 31:638-44.

12) Parker MM, Shelhamer JH, Natanson C, et al. Serial cardiovascular variables in survivors and nonsurvivors of human septic shock: heart rate as an early predictor of prognosis. Crit Care Med 1987;15:923-9.

13) Furian T, Aguiar C, Prado K, et al. Ventricular dysfunction and dilation in severe sepsis and septic shock: Relation to endothelial function and mortality. J Crit Care 2012;27:319.e9-319.e15.

14）大石一成，江藤孝史，古賀聡子，他．PMX-DHP施行時間 と血小板数の変化. 麻酔 2008; $57: 948-52$.

15) Takayama K, Yuhki K, Ono K, et al. Thromboxane A2 and prostaglandin F2alpha mediate inflammatory tachycardia. Nat Med 2005;11:562-6.

受付日 2012 年 2 月 21 日 採択日 2012 年 4 月 5 日

\title{
中毒性表皮壊死症における原因診断の困難性と感染免疫の関与
}

中毒性表皮壊死症 (toxic epidermal necrolysis, TEN）は, 皮膚粘膜の壊死性障害による紅斑や水庖, びらん, 粘膜疹をきたす重篤な疾患である。その原因 の大部分は, 薬剤性であるかもしくは細菌・マイコプ ラズマ, ウイルスなどの微生物によるとされている。 2005 年に厚生労働科学研究補助金難治性疾患克服 研究事業の重症多形滲出性紅斑に関する調査研究班に より, Stevens-Johnson症候群 (Stevens-Johnson syndrome, SJS) およびTENの診断基準が作成されて
いる11。主要な点は, 原因の大部分が医薬品であるこ と, 体表面積の $10 \%$ を超える表皮の壊死性障害, ブド ウ球菌性熱傷様皮膚症候群 (staphylococcal scalded skin syndrome, SSSS) の除外, 粘膜疹を伴うことなど である。TENの多くはSJSで発症し, その後急速に TENに進行することから, 近年ではSJSとTENは同 一範疇の疾患であって, その違いは皮膚障害の重症度 の違いとする考えが主流となっている。その発症頻度 は年間 0.3 人 $/ 100$ 万人とされるが, 発症すれば敗血症, 
多臟器不全に至る例も多く集学的な全身管理を必要と し, 死亡率 $19 \%$, 後遺症発生率 $31 \%{ }^{2)}$ という重篤な病 態になることから，筆者の施設を含めICU で経験する ことが珍しくない疾患のひとつである。

今号に扔いて大網らは溶連菌感染が示唆された TENの 1 例を報告している ${ }^{3)}$ 。比較的最近のわが国か らの報告で, 52 症例のSJSのうち 36 症例 (69.2\%) が 薬剤性とされ, 65例の TEN 症例全例が薬剤性と推定 されている4)ことからみても, これは極めて稀な 1 例 といえる。

薬疹によるSJS/TEN発症の機序は以下とされる。 すなわち，(1)表皮の抗原提示細胞であるLangerhans 細胞や標的となる表皮角化細胞の major histocompatibility complex (MHC) クラス I ・ II 抗原や non-human leukocyte antigen (non-HLA) 抗原が薬剤で修飾され てアロ抗原になる。(2)それを $\mathrm{T}$ cell receptor (TCR) により認識した $\mathrm{T}$ 細胞が活性化し, $\mathrm{CD} 8^{+} \mathrm{T} \mathrm{c} 1$ 細胞 (別名cytotoxic T lymphocyte, CTL) のバーストが起 こる。(3)産生されたtumor necrosis factor (TNF)- $a$ / interferon (IFN)- $\gamma$ が表皮角化細胞にCD95 (fas)/ CD95L (fasL) の発現誘導を促進し, 表皮角化細胞や表 皮Langerhans細胞をアポトーシスに導く，というも のである。この反応は, 薬疹の機序のうち $\mathrm{T}$ 細胞伝達 型アレルギーに分類され, さらに $\mathrm{CD} 8{ }^{+} \mathrm{T} 1$ 細胞/ $\mathrm{CD} 4^{+}$ヘルパーTc $(\mathrm{Th} / \mathrm{c})$ 細胞伝達性細胞毒性型過敏 反応 (cytotoxic type hypersensitivity reactions, CTHR）に細分類される。またこのCTHR型薬疹は, 骨髄移植に伴って見られる皮虚 graft-versus-host reaction (GVHR) に発疹学的にも組織学的にも非常に よく似ているとされている5)。

さて, 大網らの症例に扔いて, d-クロルフェニラミ ン+ベタメタゾンおよびオロパタジンに対するdruginduced lymphocyte stimulation test (DLST) は陰性 であったということであるが, その施行時期, 回数, はいかがだったであろうか。最新のわが国の全国疫学 調查 ${ }^{2)}$ に打いてもDLST の陽性率はSJS $32.3 \%$, TEN 28.6\%であったとされ，DLST陰性をもって薬凨性を 否定することは到底できない。また, DLSTの施行時 期がステロイド投与中の場合は偽陰性になることが多 い。筆者らの最近の例でも, ICUでの治療中の急性期 には 2 回陰性であったが, 7 か月後には陽性となった 症例を経験している。大網らの症例では皮疹出現前の 薬剤服用について記されていないが, 最近の報告2)で は被疑薬投与開始から皮疹出現までに 43 日以上を要 した例が $15.2 \%$ あったことに留意する必要がある。さ らに大網らが考察しているように, Mycoplasma pneumoniaeの関与については常に留意するべきであ るが, 本例ではimmunoglobulin M (IgM) 定性反応で 陽性だったものの complement fixation (CF) 法, particle agglutination (PA) 法では陰性であったこと から, 可能性は低いと考えられる。

大網らも述べているように, 感染を契機として発症 するSJS/TENの報告はMycoplasmaを除くと非常に少 ない。しかし救急集中治療医の立ち位置からすると, 本症例報告の意義のひとつはSJS/TENを疑う紅斑, 水 席,びらんなどがあったとしても，それを単なる薬疹 によるものとして捉えてしまう前に, まずは患者を目 の前にして, 皮䖉・軟部組織感染症を念頭に置いて鑑 別診断を行うことから始めることの重要性を示唆して いることにあると考えられる。皮虑・軟部組織感染症 はおおよそ炎症の部位により, 表皮に限局した病変, 真皮から皮下組織に及ぶ蜂窩織炎, 皮下組織や筋膜を 主病変とする壊死性筋膜炎 (ガスを含めばガス壊疽)に 大別される。しかし, 壊死性筋膜炎といっても炎症は 筋膜のみならず皮膚や皮下組織, 筋肉にも存在し, 蜂 窩織炎との鑑別が困難なことが多く, 欧米ではnecrotizing soft tissue infectionと一括して扱われる傾向に ある6)。この文脈の中では，もし感染症を機縁とする TENがあるとするならば，その病理的主座が表皮全 層, 水席が表皮下, 表皮剥離面が表皮真皮結合部 (dermoepidermal junction)にある軟部組織感染症と いうことになる。しかし，感染症に起因するSLS/TEN の存在を認めたとしても, それを軟部組織感染症のひ とつとして事足れりとするほど病態は単純ではない。

前述のように, TENではCTLバーストが生じ表皮 角化細胞や表皮Langerhans細胞のアポトーシスが起 こるが, 最初の段階では抗原提示細胞への抗原刺激が 必要となる。薬疹の場合は薬剤またはその代謝物質が ハプテンを形成するとされるが, 細菌においてはその 抗原性が問題になりうる。A群溶連菌の特徴として抗 原性物質が多数存在し, 中でも $\mathrm{M}$ 蛋白はその種類が 80 種以上あること, 種々の活性蛋白を細胞外に分泌す ることが知られている7)。大網らの症例では $\mathrm{A}$ 群では なくStreptococcus group Gが検出された。しかし, 劇 症型レンサ球菌感染症 (streptococcal toxic shock-like syndrome, TSLS) の原因菌はA群とされてきた背景 の中で, 近年, B, C, G 群のレンサ球菌によってTSLS と類似した臨床像を呈する症例が報告されている8)。 G群についてはその多くをS. dysgalactiae subsp. equisimilisが占めること, そのゲノム上には, 組織へ の侵入に関わる因子としてS. pyogenesの M蛋白と同 様の $e m m$ 遺伝子にコードされた $\mathrm{M}$ 蛋白を保持してい 
ることが報告されている81,9)ことから, STS/TEN発症 における G 群の関与も十分考えられ得る。また $\mathrm{A}$ 群レ ンサ球菌感染症によるTSLSは基礎疾患のない患者に 発生しやすいのに対して, B, C, G 群感染症では既往 歴に肝硬変, 糖尿病, ステロイド投与などのある免疫 不全患者に発症することが多い10)とされ，この点も ICU患者では留意すべきことと思われる。

さて, TENと同様に重症薬疹としてICUで経験す る疾患として薬郕過敏性症候群 (drug-induced hypersensitivity syndrome, DIHS) があり，表皮壊死が見ら れないことでSTS/TENと異なるが,ここにおいて human herpesvirus 6 (HHV-6)の再活性化が報告され ている11)。これと関連して, 薬疹発症機序としてまず ウイルス感染があり, ウイルス性発疹の部位に残存し たT細胞が薬剤と交差反応して中毒疹になるという考

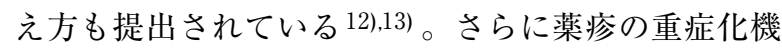
序に抒いてdamage-associated molecular pattern molecules (DAMPs) 遺伝子発現の光進が示され ${ }^{14)}$ ，ま た最近 Nakajima ら ${ }^{15)} は$ は, TEN と high mobility box-1 protein (HMGB1) との関連を研究し, TENにおいて はHMGB1 が発症初期から極期 (発症21日くらい)ま で他の型の薬疹より高值であることから, HMGB1の 早期マーカとしての意義を報告している。今やSJS/ TENに扔いては, 薬疹か感染かでなく, 重症化の機序 にalarmin と呼ばれる細胞・組織損傷産物, 細胞外基 質変性物質, 活性化細胞分泌物資などからなる DAMPsによる生体侵襲が関与していることが想定さ れている。救急集中治療医のまさに専門としている領 域がSJS/TENに㧍けるsystemic inflammatory response syndrome (SIRS), 感染免疫, 多臟器不全へ の進行の本態をなしており, 本疾患は, ICUにおける 臨床研究にとっても宝の山と言うべきであろう。

\section{本稿の著者には規定されたCOIはない。}

\author{
貝沼 関志 $* 1,2$ \\ *1名古屋大学医学部附属病院外科系集中治療部 \\ *2名古屋大学大学院医学系研究科機能構築医学専攻生 \\ 体管理医学講座麻酔・蘇生医学 \\ （４ 466-8550 愛知県名古屋市昭和区鶴舞町 65）
}

The difficulty of diagnosing the cause and the participation of infection immunity in toxic epidermal necrolysis

Key words: (1) toxic epidermal necrolysis, (2) Stevens-Johnson syndrome, (3) Streptococcus group G
Motoshi Kainuma

Division of Surgical Intensive Care Medicine, Department of Anesthesiology, Nagoya University Graduate School of Medicine

65 Tsurumai-cho, Sowa-ku, Nagoya, Aichi 466-8550, Japan

J Jpn Soc Intensive Care Med 2012;19:314-6.

\section{文 献}

1) 相原道子, 狩野葉子, 飯島正文, 他. Stevens-Johnson症 候群㧍よび中毒性表皮壊死症 (TEN) の治療方針 一平成 20 年度厚生労働科学研究費補助金 (難治性疾患克服研究事業) 重症多形渗出性紅斑に関する調查研究班による治療指針 2009の解説一. 日皮会誌 2009;119:2157-63.

2) 北見 周, 渡辺秀晃, 末木博彦, 他. Stevens-Johnson 症 候群ならびに中毒性表皮壊死症の全国疫学調查 —平成 20 年度厚生労働科学研究費補助金 (難治性疾患克服研究事業) 重症多形渗出性紅斑に関する調查研究. 日皮会誌 2011 ; 121:2467-82.

3) 大網毅彦, 中西加寿也, 大島 拓, 他. 溶連菌感染の関与 が示唆された中毒性表皮壊死症の1例。日集中医誌 2012;19:409-13.

4) Yamane Y, Aihara M, Ikezawa Z. Analysis of StevensJohnson syndrome and toxic epidermal necrolysis in Japan from 2000 to 2006. Allergol Int 2007;56:419-25.

5) 池澤善郎. 薬疹, 中毒疹. 植木宏明, 富田 靖, 玉置邦彦, 他編. 皮膚科専門医テキス卜 改訂第 2 版. 東京: 南江堂; 2002. p. 398-415.

6) McHenry CR, Piotrowski JJ, Petrinic D, et al. Determinants of mortality for necrotizing soft-tissue infections. Ann Surg 1995;221:558-63.

7) 井上雄二, 城野昌義, 葉 著寿, 他. 劇症溶連菌感染症一 Tocxic Shock-like syndrome一. 西日皮 1995;57:494-8.

8) 生方公子, 砂押克彦, 小林玲子, 他. C群およびG 群溶血 性レンサ球菌による侵襲性感染症についてのアンケート調 査. 感染症誌 2006;80:480-7.

9) Ikebe T, Murayama S, Saitoh K, et al; Working Group for Streptococci in Japan. Surveillance of severe invasive group-G streptococcal infections and molecular typing of the isolates in Japan. Epidemiol Infect 2004;132:145-9.

10）丹野 英, 大江恭司, 清水可方, 他. $\beta$ 溶血性 $\mathrm{G}$ 群レンサ 球菌による toxic shock like syndrome 一股関節離断術に より救命しえた 1 症例. 日集中医誌 2000;7:115-20.

11) Suzuki Y, Inagi R, Aono T, et al. Human herpesvirus 6 infection as a risk factor for the development of severe drug-induced hypersensitivity syndrome. Arch Dermatol 1998;134:1108-12.

12) 塩原哲夫. 薬疹の概念 —ここまで広がった薬疹の概念. 医のあゆみ 2011;238:755-60.

13) Lavergne SN, Wang H, Callan HE, et al. "Danger” conditions increase sulfamethoxazole-protein adduct formation in human antigen-presenting cells. J Pharmacol Exp Ther 2009;331:372-81.

14) Bellón T, Alvarez L, Mayorga C, et al. Differential gene expression in drug hypersensitivity reactions: induction of alarmins in severe bullous diseases. Br J Dermatol 2010;162:1014-22

15) Nakajima S, Watanabe H, Tohyama M, et al. Highmobility group box 1 protein (HMGB1) as a novel diagnostic tool for toxic epidermal necrolysis and StevensJohnson syndrome. Arch Dermatol 2011;147:1110-2. 